\title{
In Vitro Evaluation of Antibacterial Potential of Cerastes Vipera Venom against Gram-Positive and Gram-Negative Bacterial Strains
}

Samy A. Saber ${ }^{1}$, Aly F. Mohamed ${ }^{2}$, Abir A. El-Fiky ${ }^{3}$, Hossam. H. Eldaly*

${ }^{1}$ Department of Zoology, Faculty of Science (Boys branch), Al-Azhar University, Cairo, Egypt;

${ }^{2}$ R\&D Sector VACSERA and ${ }^{3}$ ANDI COE in Antivenom Research

*Corresponding author: Hossam Eldaly, Mobile: (+20)1114822801, Email: hossameldaly3@gmail.com

\begin{abstract}
Background: Venoms of the family Viperidae in particular are complex mixture of many substances. They include many different proteins that possess significant bactericidal inhibition.

Objectives: The aim of the current work was to investigate the antibacterial profile of Sahara sand viper (Cerastes vipera) snake venom against both gram negative Pseudomonas aeruginosa and gram-positive bacteria Bacillus cereus.

Materials and Methods: 1. Identification of the venom was performed using assessment of total protein, determination of the venom protein by SDS-PAGE electrophoresis and determination of the half lethal dose (LD50) of venom. 2. Antibacterial activities of Cerastes vipera venom was examined by using disc diffusion method. Microdilution method was used to determine the venom's minimum inhibitory concentration (MIC) and the minimum bactericidal concentration $(\mathrm{MBC}) .3$. The interaction between venom and bacteria was examined by Electron microscope.

Results: The total protein of the venom was $1.047 \pm 0.1 \mathrm{mg} / \mathrm{ml}$. The SDS electrophoresis showed there were four clear bands of protein nearly at 25, 35, 48, $63 \mathrm{Kds}$ and another band between 25, and $35 \mathrm{Kds}$. The LD50 was 18.3 $\mu \mathrm{g} / \mathrm{mouse}(0.915 \mathrm{mg} / \mathrm{kg}$ body weight). Concerning the antibacterial effect of tested venom, disc diffusion test showed a ring of inhibition zone of about $12 \mathrm{~mm}$ in the case of Pseudomonas aeruginosa and of about $0.8 \mathrm{~mm}$ in the case of Bacillus cereus. The Microdilution test showed that the MIC of the venom for Pseudomonas aeruginosa was $12.5 \mathrm{mg} / \mathrm{ml}$ and that for Bacillus cereus was $25 \mathrm{mg} / \mathrm{ml}$. The electron microscopic examination supported the two previous tests, as it observed the presence of elongated, malformed, melted, no-membranous and lysed bacterial cells when treated by the venom.

Conclusion: It could be concluded that Cerastes vipera venom is a potentially weak bactericidal, but can inhibit antibiotic-resistant bacteria as Pseudomonas aeruginosa.
\end{abstract}

Keywords: Cerastes vipera venom, bactericidal, Bacillus cereus, Pseudomonas aeruginosa, MIC, MBC, Electron microscopic examination.

\section{INTRODUCTION}

Egypt as a desert land comprises different species of venomous animals including snakes. In Egypt, 1000-10,000 incidences of snake's envenomation per year with about 11-100 death cases annually ${ }^{(1)}$. Cerastes vipera is one of the most venomous snakes of Egypt. Sahara Sand Viper (Cerastes vipera) is a venomous viper species endemic to the deserts of North Africa and the Sinai Peninsula (2).

Antimicrobial resistance is an increasingly serious worldwide threat associated with millions of illnesses and deaths annually over the world. Antimicrobial resistance is predicted to cause ten million deaths in $2050^{\text {(3) }}$. Given its vast ability as the source of therapeutics, it was found that viper venom has antimicrobial activity against gram-positive and gramnegative bacteria ${ }^{(4)}$. The venom antimicrobial activity was due to enzymes such as L-amino acid oxidase ${ }^{(5)}$.

The antimicrobial potential of snake venom enzymes is widely investigated. PLA2 and L-amino acid oxidases (LAAOl and LAAO2) are among the best studied enzymes associated with antibacterial properties ${ }^{(6)}$. Both PLA2 and LAAO are usually responsible for the major toxic effects during snake envenomation.

The aim of the current work was to investigate the antibacterial profile of Sahara sand viper (Cerastes vipera) snake venom against both gram negative Pseudomonas aeruginosa and gram-positive bacteria Bacillus cereus.

\section{MATERIALS AND METHODS}

\section{Ethical approval:}

The study was approved by the Ethics Board of AlAzhar University.

Snake venom collection: Lyophilized pure venom of Sahara sand viper (Cerastes vipera) was obtained from ANDI COE, VACSERA, where venom was stored in brown vial at refrigerator $\left(4^{\circ} \mathrm{C}\right)$ till used.

Strains: Pseudomonas aeruginosa was obtained from American Type Culture Collection number 27853(ATCC). Bacillus cereus was obtained from the microbial chemistry department, National Research Center. 
Inoculums Preparation: A loopful from the overnight growth was transferred to $50 \mathrm{ml}$ Tryptone Soya Broth (TSB) medium and was incubated at $37^{\circ} \mathrm{C}$ with vigorous shaking $(150 \mathrm{rpm})$ for $18 \mathrm{~h}$; cell growth was checked purity by Gram stain.

Total Protein: Total protein content was determined at center of excellence in anti-venom research EGYVAC, VACSERA according to Lowry et al. ${ }^{(7)}$.

Determination of the venom protein by SDS-PAGE electrophoresis. The venom protein activity was also assayed by electrophoresis in SDS-PAGE Laemmli ${ }^{(8)}$ (12\% acrylamide gel under reducin gcondition) with co-polymerized gelatin. The venom samples $(10 \mathrm{mg})$ diluted in $0.05 \mathrm{M}$ TRIS-glycine buffer, $\mathrm{pH}$ 6.8, containing $10 \%$ glycerol, $0.025 \mathrm{M}$ SDS, and 0.5 $\mathrm{mg} / \mathrm{ml}$ phenol red were directly applied on the gel. Soon after the run at $150 \mathrm{~V}$ for about 3 hours at $4^{\circ} \mathrm{C}$, the gel was then (a) incubated at $37^{\circ} \mathrm{C}$ in $0.1 \mathrm{M}$ glycine- $\mathrm{NaOH}, \mathrm{pH} 9.5$, for 5 hours, and (b) developed for proteolytic activity with $0.1 \%$ Amido Black in methanol: acetic acid: water (3:1:6; v:v:v). The gels were de-stained with methanol: acetic acid: water (3:1:6; v:v:v) until the clear zones of protein could be seen.

\section{Determination of LD50 of venom:}

The LD50 of the venom was determined according to the method of British Pharmacopeia (2000), Reed and Muench (9), using male albino Swiss mice 20 grams. Ascending concentration of 5 dose levels of the freshly prepared venom solution in normal saline with an increasing factor 1.2 , starting by a dose which kills approximately $0-20 \%$ of the animals and ending by a dose which kills approximately 80-100 \% of the injected animals. Each dose level was tested in 4 mice, and all injections were given intravenously.

Disc diffusion method: The surface of the plates was uniformly covered with the bacterial growth for Pseudomonas aeruginosa and Bacillus cereus which re-suspended and adjusted turbidity to $0.5 \mathrm{McFarland}$ (10). The sterile filter paper discs were impregnated in venom with concentration of $100 \mathrm{mg}$ venom $/ 1 \mathrm{ml}$ saline.

- Disc of antibiotics like erythromycin (15 $\mu \mathrm{g}$ Oxoid lot no. 1876568), Ampicillin (10 $\mu$ g Oxoid lot no. 1843425), Amikacin (30 $\mu$ g Oxoid lot no.2288626) and Ciprofloxacin (5 $\mu$ g Oxoid lot no.2280856) as positive control. The discs were placed on the surface of the plates suitably spaced apart, and then the plate was incubated at $37^{\circ} \mathrm{C}$ for $18 \mathrm{hrs}$. The plate was examined for the presence of zone of inhibition for bacterial growth around the disc. The zone of inhibition was indicative the degree of organism sensitivity ${ }^{(11)}$.

The minimum inhibitory concentration (MIC) and minimum bactericidal concentration (MBC):

The bacterial growth was re-suspended and adjusted turbidity to 0.5 McFarland (10) using spectrophotometer (Perkin Elmer-EZ 301-German) for Pseudomonas aeruginosa and Bacillus cereus according to Andrews ${ }^{(\mathbf{1 2})}, 100 \mathrm{mg}$ venom $/ 1 \mathrm{ml}$ saline. $100 \mu 1$ of standard McFarland ${ }^{(\mathbf{1 0 )}}$ bacterial growth of each strain was pipette into each well of a microtiter plate (96 Well CELLSTAR ${ }^{\circ}$, Greiner Bio-One $\mathrm{GmbH}$ ). Wells no. $1 \& 2$ were positive control and Wells no. $11 \& 12$ were negative control. $100 \mu$ l of antibiotic was pipette into wells no. $3 \& 4$ as positive control. The plate 1 for Bacillus cereus, a serial dilution $(1 / 2-1 / 64)$ from concentration of $100 \mathrm{mg}$ venom $/ 1 \mathrm{ml}$ saline was added from well no. 3 to well number 10. The plate 2 for Pseudomonas aeruginosa, a serial dilution $(1 / 2-1 / 64)$ from concentration of $100 \mathrm{mg}$ venom $/ 1 \mathrm{ml}$ saline was added from well no. 3 to well number 10 . The plates were incubated at $37^{\circ} \mathrm{C}$ for overnight. The plates were read on ELISA reader (Biotek- ELX800- USA) at wavelength $570 \mathrm{~nm}$.

Electron microscopic examination: Preparation of the sample: 1-Bacteria:

A loopful from the overnight growth was transferred to $50 \mathrm{ml}$ Tryptone Soya Broth (TSB) medium and was incubated at $37^{\circ} \mathrm{C}$ with vigorous shaking $(150 \mathrm{rpm})$ for $18 \mathrm{~h}$; cell growth was checked purity by Gram stain. 2-Specimen: The Prepared bacteria was mixed with the MIC of the venom and incubated at $37^{\circ} \mathrm{C}$ for 48 hours.

\section{Negative Stain Biological Specimen Preparation} (Non sonicator):

1) Use a $10 \mathrm{ml}$ disposable pipet to resuspend the cells by pipetting up and down.

2) Place 2-5 ul drops of specimen onto sheet of Parafilm.

3) Make EM grids (carbon-coated 400-mesh copper grids) directly off on specimen.

4) Use filter paper to wick away specimen drop.

5) Place grid on drop of filtered 2\% PTA stain, $\mathrm{pH} 7.0$, and let stain for30-60 sec.

6) Use filter paper to wick away stain and place grids, specimen-side up in specimen petri dish.

\section{RESULTS}

\section{Experiment I: venom identification}

Assessment of Total protein:

Table 1showed the value of total protein of Cerastes vipera venom which equal 1.047 \pm 0.1 $\mathrm{mg} / \mathrm{ml}$.

Table 1: Total protein of Cerastes vipera venom

\begin{tabular}{|l|l|l|l|}
\hline $\begin{array}{l}\text { Protein } \\
\text { concentration }\end{array}$ & $\begin{array}{l}\text { Warburg and } \\
\text { Christian, } \\
1942^{(12)}\end{array}$ & $\begin{array}{l}\text { Up to 2 } \\
\mathrm{mg} / \mathrm{ml}\end{array}$ & $\begin{array}{c}1.047 \pm 0.1 \\
\mathrm{mg} / \mathrm{ml}\end{array}$ \\
\hline
\end{tabular}


Biochemical characterization by SDS page electrophoresis

From fig. 1 we can represent four clear bands of protein nearly at $25,35,48,63$, Kds and another band bet ween 25 and $35 \mathrm{Kds}$.

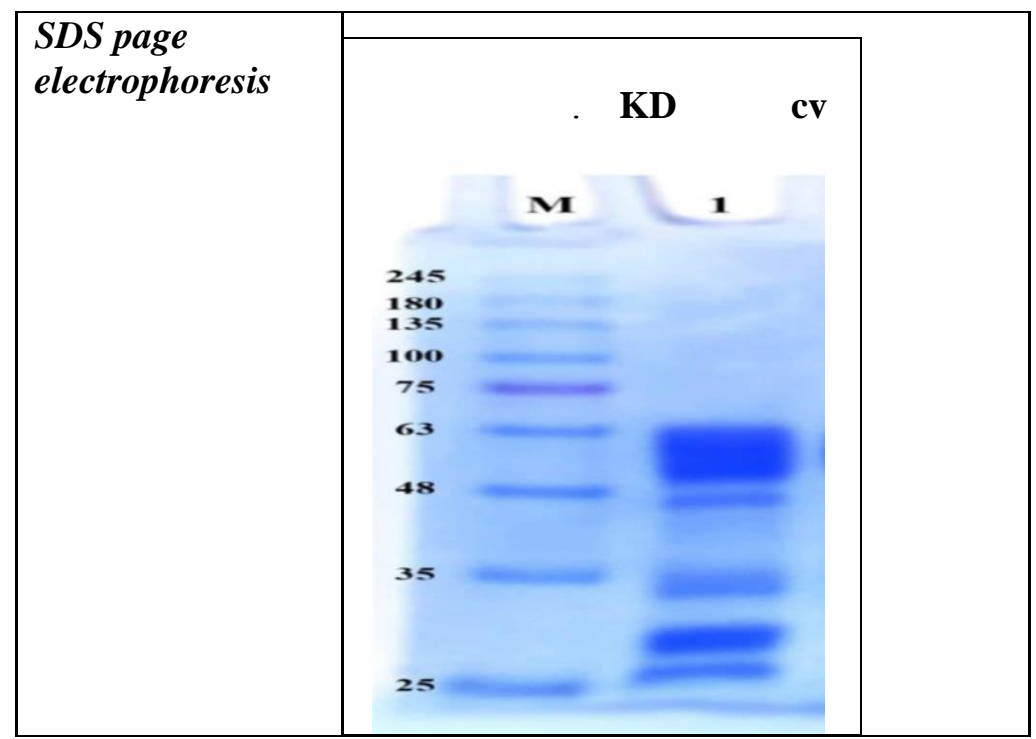

Fig.1. SDS page electrophoresis for Cerastes vipera venom

The assessment of half lethal dose (LD50):

Table 2 and figure 2 showed the approximate half lethal dose (LD50) of Cerastes vipera venom that assessed according to Reed and Muench, (1938) ${ }^{(11)}$.

LD50 $=18.3 \mu \mathrm{g} / \mathrm{mouse}(0.915 \mathrm{mg} / \mathrm{kg}$ body weight $)$.

Table 2: Lethality of Cerastes vipera venom injected $\mathrm{I} / \mathrm{V}$ in Swiss-albino mice and estimated value of $\mathrm{LD}_{50}$

\begin{tabular}{rrrrrrr}
\hline Dose $(\mu \mathrm{g} / \mathrm{mouse})$ & \multicolumn{6}{c}{ Accumulated Values } \\
\hline & Died & Survived & Died & Survived & Mortality Ratio (\%) \\
\hline 11.5 & 0 & 5 & 0 & 15 & $00.0 \%$ \\
13.8 & 1 & 4 & 1 & 10 & $0.9 \%$ \\
16.6 & 2 & 3 & 3 & 6 & $33.3 \%$ \\
20 & 3 & 2 & 6 & 3 & $66.6 \%$ \\
24 & 4 & 1 & 10 & 1 & $90.9 \%$ \\
28.8 & 5 & 0 & 15 & 0 & $100 \%$ \\
\hline
\end{tabular}

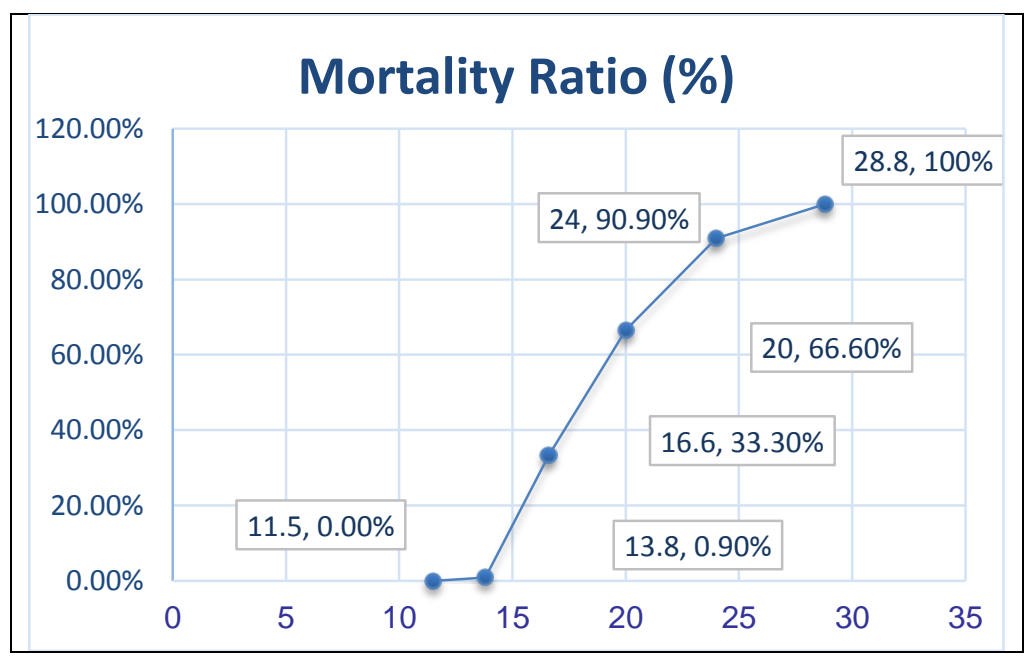

Fig. 2: Mortality curve of Swiss Albino mice administrated different doses of Cerastes vipera venom 
Experiment II: Antibacterial effect of Cerastes vipera venom:

A) Model of gram-negative bacteria: Pseudomonas aeruginosa

\section{Disc diffusion}

The disc diffusion method was used to assess the antibacterial effect of Cerastes vipera venom compared with the same standard antibiotics; Erythromycin (E), Ampicillin (AMP), Ciprofloxacin (CIP) and Amikacin (AK), against Pseudomonas aeruginosa (Table 3).

Table 3: In vitro antibacterial activity of Cerastes vipera crude venom $(20 \mathrm{mg} / \mathrm{ml})$ against pseudomonas aeruginosa strain using disc diffusion method and compared to four antibiotics (stander disc). (Mean \pm S.D) of inhibition zone in $\mathbf{m m}$.

\begin{tabular}{||l|l|}
\hline Antibiotics / Venom & Inhibition zone \\
\hline \hline Cerastes vipera venom $(20 \mathrm{mg} / \mathrm{ml})$ & $(12 \pm 0.1) \mathrm{mm}$ \\
\hline \hline Ampicillin $(10 \mu \mathrm{g} / \mathrm{ml})$ & $(0.0 \pm 0.0) \mathrm{mm}$ \\
\hline Erythromycin $(15 \mu \mathrm{g} / \mathrm{ml})$ & $(0.0 \pm 0.0) \mathrm{mm}$ \\
\hline Ciprofloxacin $(5 \mu \mathrm{g} / \mathrm{ml})$ & $(30 \pm 0.11) \mathrm{mm}$ \\
\hline Amikacin $(30 \mu \mathrm{g} / \mathrm{ml})$ & $(20 \pm 0.09) \mathrm{mm}$ \\
\hline
\end{tabular}

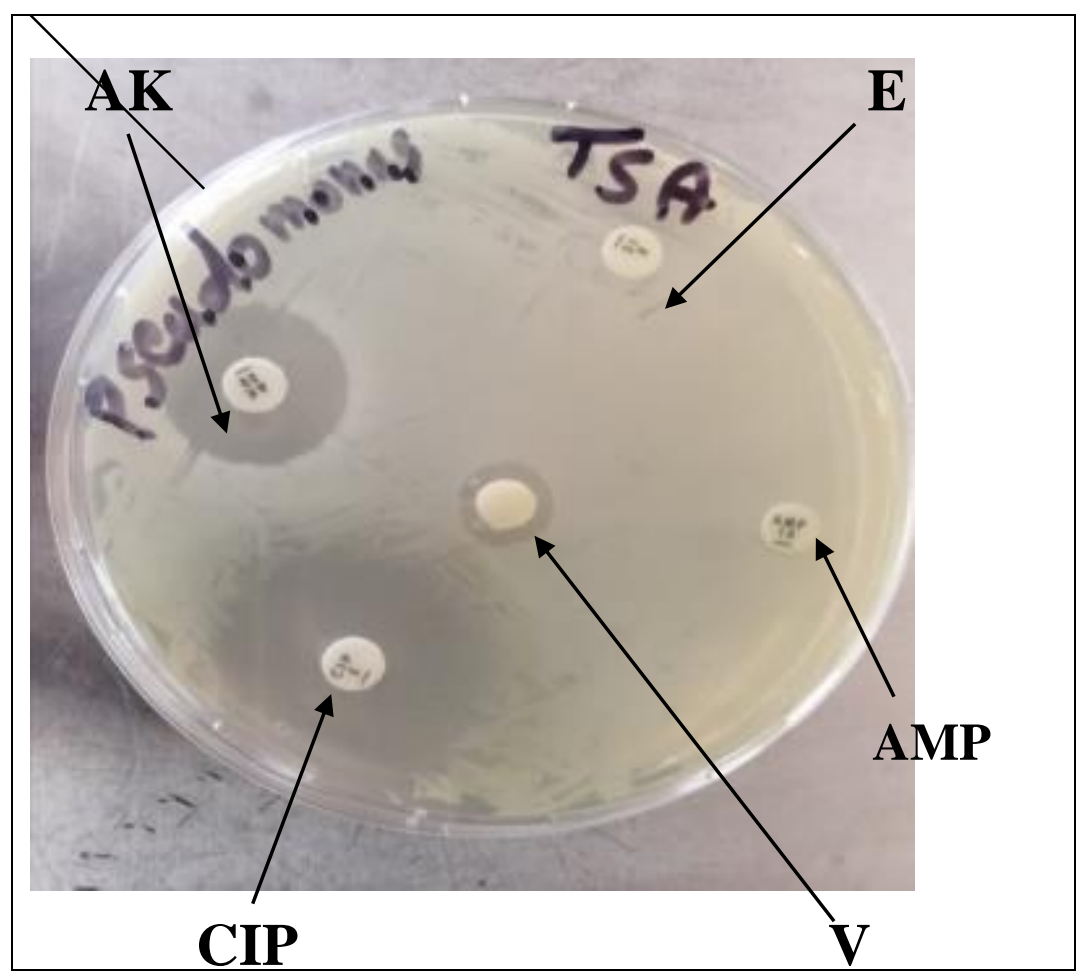

Fig.3: Antibacterial effect of Cerastes vipera venom (V) against pseudomonas aeruginosa in compared with four antibiotics; Ampicillin (AMP), Erythromycin (E), Ciprofloxacin (CIP) and Amikacin (AK)

There was a highly effective antibacterial effect of Ciprofloxacin antibiotic with the pseudomonas aeruginosa bacterial growth producing a wide ring of inhibition zone average; $30 \mathrm{~mm}$, Amikacin antibiotic produced intermediate ring of inhibition zone about $20 \mathrm{~mm}$, However the Cerastes vipera venom produced low ring of inhibition zone of about $12 \mathrm{~mm}$ and Ampicillin and Erythromycin produced no inhibition zone (resistance) as shown in (Table 3\&Fig. 3).

\section{Determination of Minimum Inhibitory Concentration (MIC)}

From table 4, and figure 4, It can be observed that the minimum Inhibitory concentration (MIC) of Cerastes vipera venom in the case of Pseudomonas aeruginosa is $12.5 \mathrm{mg} / \mathrm{ml}$ which gave inhibition value equal $0.68 \pm 0.011$ and it is higher than the MIC of tylosin antibiotic for the same bacteria that is $10 \mathrm{mg} / \mathrm{ml}$ which gave 
inhibition value equal $2.52 \pm 0.16$.

Table 4: Determination of Minimum Inhibitory Concentration (MIC) for Pseudomonas aeruginosa

\begin{tabular}{|c|c|c|c|c|}
\hline Pseudomonas aeruginosa & Tylosin & Venom & control + & control- \\
\hline MIC value (concentration) & $10 \mathrm{mg} / \mathrm{ml}$ & $12.5 \mathrm{mg} / \mathrm{ml}$ & $\begin{array}{l}0.5 \mathrm{Mcf} \\
\text { bacteria }\end{array}$ & media \\
\hline Inhibition value & $2.52 \pm 0.16$ & $0.68 \pm 0.011$ & $1.72 \pm 0.045$ & $\begin{array}{l}0.24 \pm 0.04 \\
0.37 \pm 0.035\end{array}$ \\
\hline \multicolumn{5}{|c|}{$\begin{array}{l}\text { MIC values are given as mean of five replicates }(\mathrm{n}=8) \text {, the bacterial inoculums per plate } \\
\text { contained } 3.2 \times 10^{8} \mathrm{cfu} / \mathrm{mL} \text { forming units/well, Control }(0.5 \mathrm{MQ}) \text { (bacterial inoculums); } \\
\text { venom breaking points (MICs } 12.5 \mathrm{mg} / \mathrm{mL}) \text { against } P \text {. aeruginosa bacteria, Results is } \\
\text { expressed by mean } \pm \text { SD }\end{array}$} \\
\hline
\end{tabular}

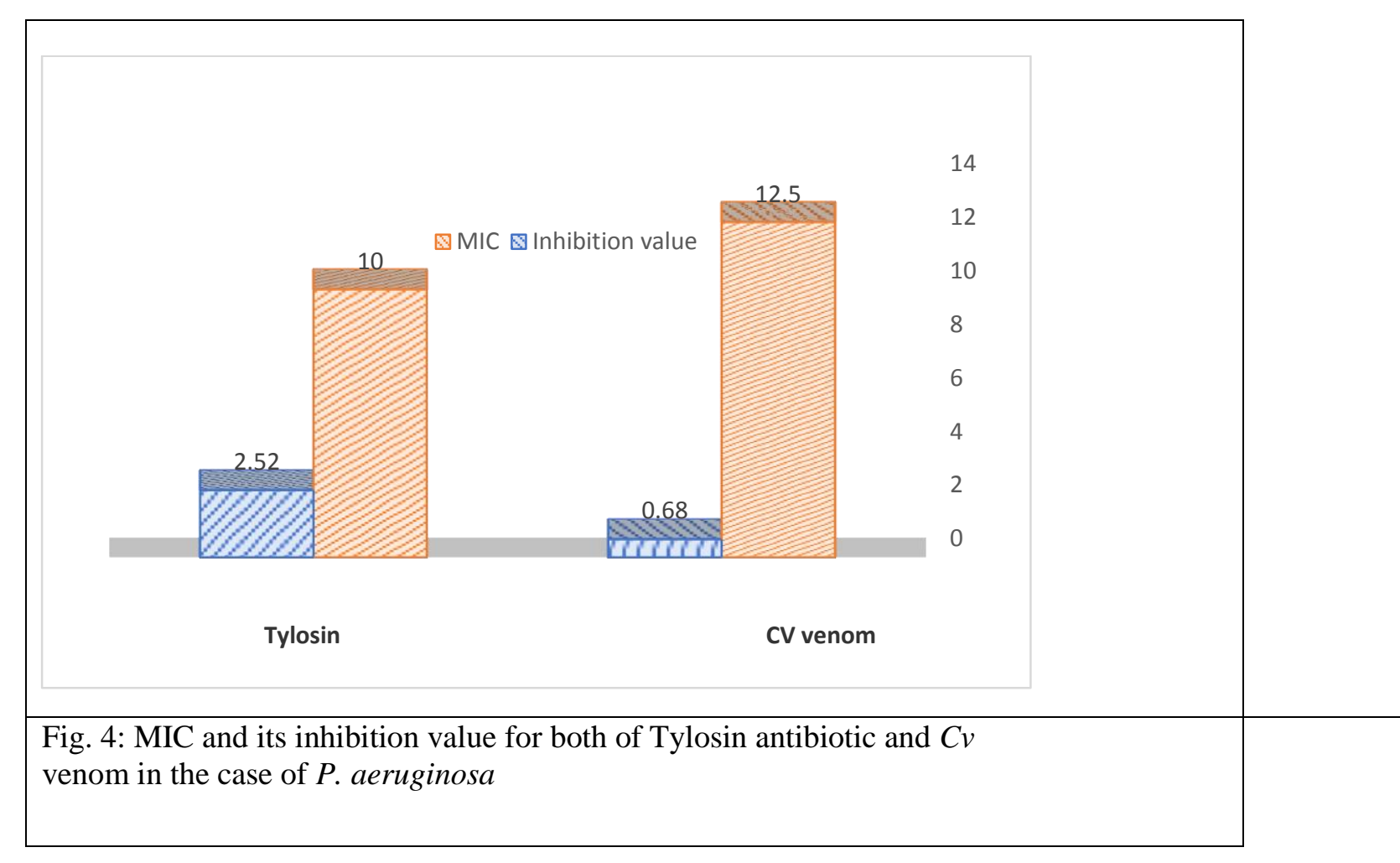

\section{Determination of Minimum Bactericidal Concentration (MBC)}

From table 5, and figure 5, It can be observed that the minimum bactericidal concentration (MBC) of Cerastes vipera venom in the case of Pseudomonas aeruginosa is $25 \mathrm{mg} / \mathrm{ml}$ which gave inhibition value equal $0.82 \pm 0.009$ and it is higher than the MBC of tylosin antibiotic for the same bacteria that is $20 \mathrm{mg} / \mathrm{ml}$ which gave inhibition value equal $3.5 \pm 0.18$

Table 5: Determination of the Minimum Bactericidal Concentration (MBC) of Cv for (Pseudomonas aeruginosa)

\begin{tabular}{|l|l|c|c|c|}
\hline Pseudomonas aeruginosa & tylosin & $\mathrm{cv}$ & control + & control- \\
\hline $\begin{array}{l}\text { MBC value } \\
\text { (concentration) }\end{array}$ & $20 \mathrm{mg} / \mathrm{ml}$ & $25 \mathrm{mg} / \mathrm{ml}$ & $0.5 \mathrm{Mcf}$ bacter & media \\
\hline Inhibition value & $3.5 \pm 0.18$ & $0.82 \pm 0.009$ & $1.72 \pm 0.045$ & $0.37 \pm 0.035$ \\
\hline
\end{tabular}




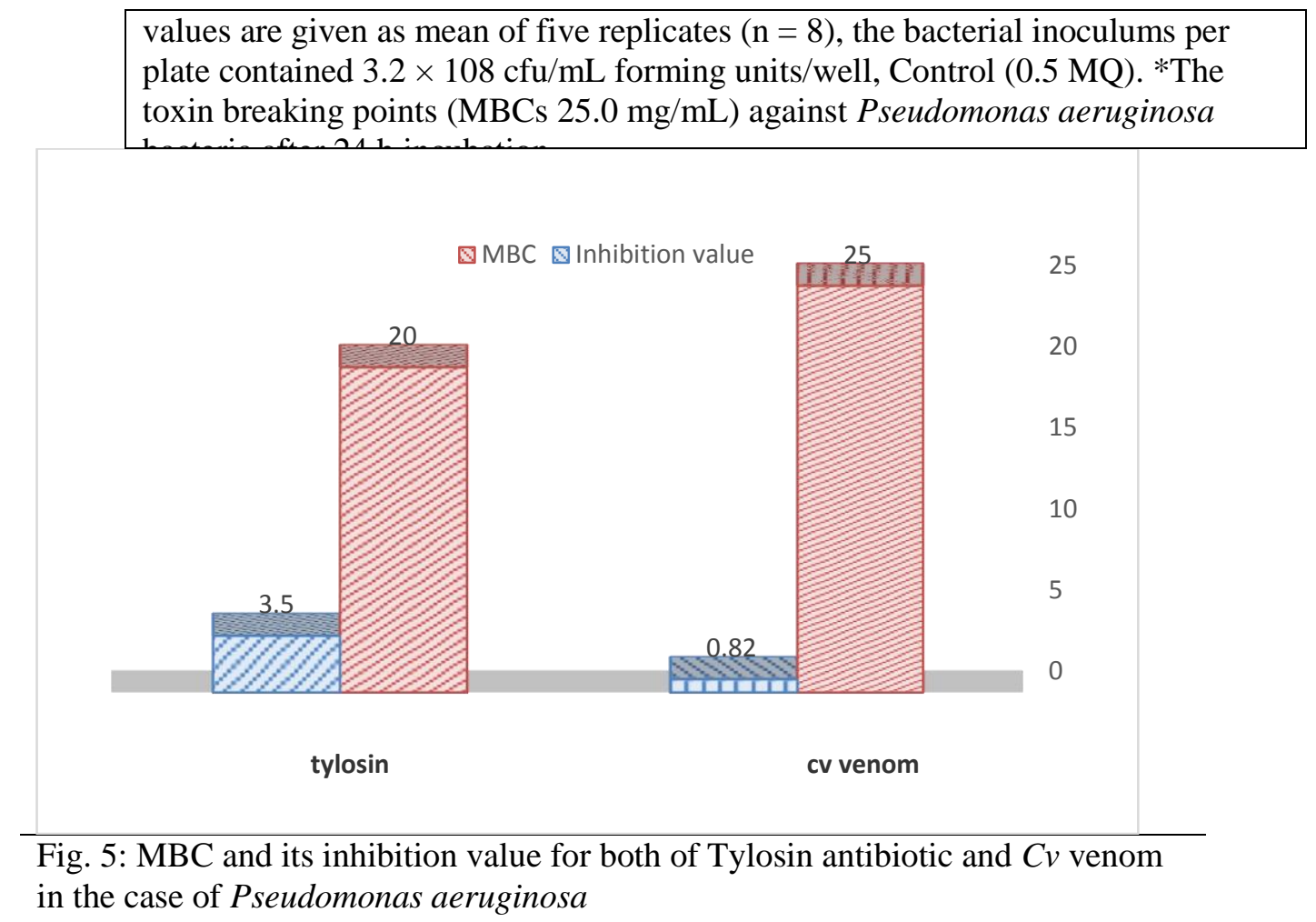

B) Model of gram-positive bacteria: Bacillus cereus

\section{Disc diffusion}

The disc diffusion method was used to assess the antibacterial effect of Cerastes vipera venom compared with different standard antibiotics; Erythromycin (E), Ampicillin (AMP), Ciprofloxacin (CIP) and Amikacin (AK), against Bacillus cereus Table 6 and figure 6.

Table 6: In vitro antibacterial activity of Cerastes vipera crude venom $(20 \mathrm{mg} / \mathrm{ml})$ against bacillus cereus strain using disc diffusion method and compared to four antibiotics (stander disc). (Mean \pm S.D) of inhibition zone in $\mathbf{m m}$.

\begin{tabular}{|l|l||}
\hline Antibiotics / Venom & Inhibition zone/mm \\
\hline \hline Cerastes vipera venom $(20 \mathrm{mg} / \mathrm{ml})$ & $8 \pm 0.2$ \\
\hline \hline Ampicillin $(10 \mu \mathrm{g} / \mathrm{ml})$ & $20 \pm 0.12$ \\
\hline Erythromycin $(15 \mu \mathrm{g} / \mathrm{ml})$ & $32 \pm 0.09$ \\
\hline \hline Ciprofloxacin $(5 \mu \mathrm{g} / \mathrm{ml})$ & $40 \pm 0.11$ \\
\hline \hline Amikacin $(30 \mu \mathrm{g} / \mathrm{ml})$ & $28 \pm 0.09$ \\
\hline
\end{tabular}




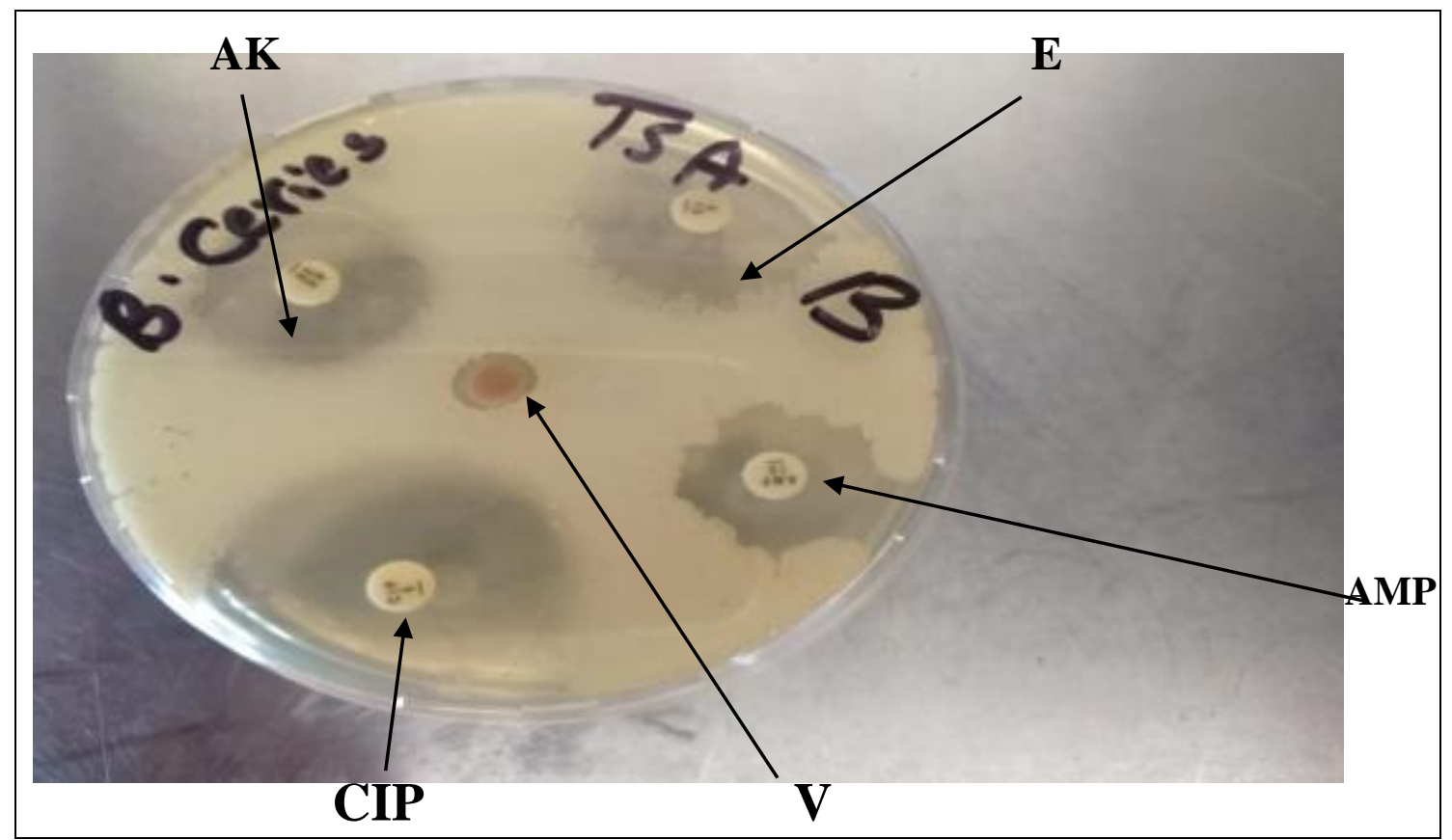

Fig.6: Antibacterial effect of Cerastes vipera venom (V) against Bacillus cereus in compared with four antibiotics; Ampicillin (AMP), Erythromycin (E), Ciprofloxacin (CIP) and Amikacin (AK)

There was a highly effective antibacterial effect of Ciprofloxacin, Erythromycin and Amikacin antibiotics produced a wide ring of inhibition zone about 40,32, $28 \mathrm{~mm}$ respectively, while the Ampicillin antibiotic produced intermediate inhibition zone average; $20 \mathrm{~mm}$ and the Cerastes vipera venom produced low ring of inhibition zone of about $8 \mathrm{~mm}$, all with the Bacillus cereus bacterial growth (Table6 \& Fig.6).

\section{Determination of the Minimum Inhibitory Concentration (MIC)}

From table 7, and figure 7, It can be observed that the minimum inhibitory concentration (MIC) of Cerastes vipera venom in the case of bacillus cereus is $25 \mathrm{mg} / \mathrm{ml}$ which give inhibition value equal $0.8 \pm 0.062$ and it is higher than the MIC of oxytetracycline antibiotic for the same bacteria that is $5 \mathrm{mg} / \mathrm{ml}$ which give inhibition value equal $0.66 \pm 0.028$.

Table 7: Determination of Minimum Inhibitory Concentration (MIC) for Bacillus cereus

\begin{tabular}{|l|l|c|c|c|}
\hline Bacillus cereus & oxytetracycline & venom & control & Control- \\
\hline MIC value (concentration) & $5 \mathrm{mg} / \mathrm{ml}$ & $25 \mathrm{mg} / \mathrm{ml}$ & $\begin{array}{l}0.5 \mathrm{Mcf} \\
\text { bacteria }\end{array}$ & media \\
\hline Inhibition value & $0.66 \pm 0.028$ & $0.8 \pm 0.062$ & $1.83 \pm 0.032$ & $0.42 \pm 0.045$ \\
\hline $\begin{array}{l}\text { MIC values are given as mean of five replicates }(\mathrm{n}=8) \text {, the bacterial inoculums per plate } \\
\text { contained } 3.2 \times 108 \mathrm{cfu} / \mathrm{mL} \text { forming units/well, Control }(0.5 \mathrm{MQ}) \text { (bacterial inoculums); } \\
\text { venom breaking points }(\mathrm{MICs} 25 \mathrm{mg} / \mathrm{mL}) \text { against } P \text {. aeruginosa bacteria. Results } \\
\text { represented by mean } \pm \mathrm{SD}\end{array}$ \\
\hline
\end{tabular}




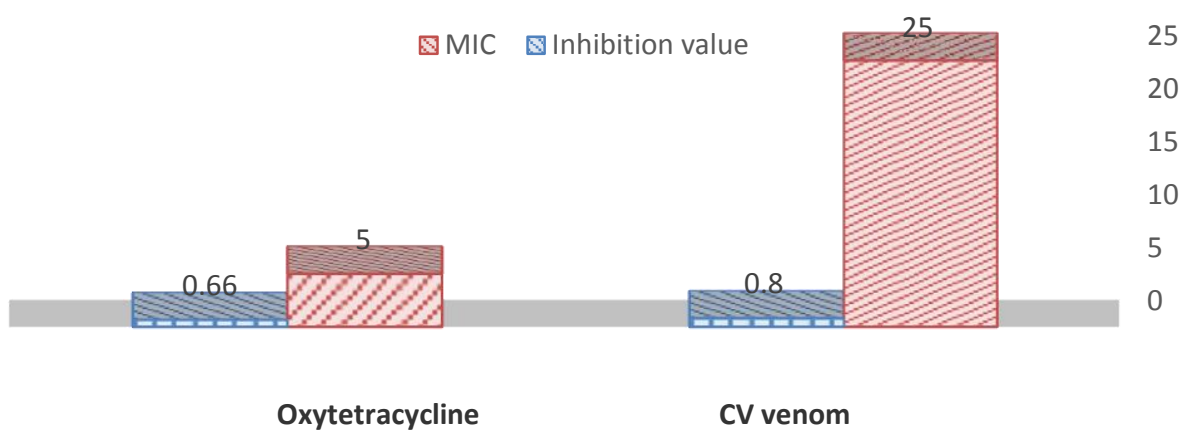

Fig. 7: MIC and its inhibition value for both of oxytetracycline antibiotic and $C v$ venom in the case of B. cereus

\section{Determination of the Minimum Bactericidal Concentration (MBC)}

From table 8, and figure 8, It can be observed that the minimum Bactericidal concentration (MBC) of Cerastes vipera venom in the case of Bacillus cereus is $50 \mathrm{mg} / \mathrm{ml}$ which give inhibition value equal $0.87 \pm 0.07$ and it is higher than the MBC of oxytetracycline antibiotic for the same bacteria that is $10 \mathrm{mg} / \mathrm{ml}$ which give inhibition value equal $0.80 \pm 0.03$.

Table 8: Determination of the Minimum Bactericidal Concentration (MBC) for Bacillus cereus

\begin{tabular}{|l|l|l|l|l|}
\hline Bacillus cereus & oxytetracycline & venom & control & control- \\
\hline MBC value (concentration) & $10 \mathrm{mg} / \mathrm{ml}$ & $50 \mathrm{mg} / \mathrm{ml}$ & $\begin{array}{l}0.5 \mathrm{Mcf} \\
\text { bacteria }\end{array}$ & media \\
\hline Inhibition value & $0.80 \pm 0.03$ & $0.87 \pm 0.07$ & $1.83 \pm 0.032$ & $0.42 \pm 0.045$ \\
\hline \multicolumn{3}{|l|}{} & & values are given as mean of five replicates $(\mathrm{n}=8)$, the bacterial inoculums per plate \\
contained $3.2 \times 108 \mathrm{cfu} / \mathrm{mL}$ forming units $/ \mathrm{well}, \mathrm{Control}(0.5 \mathrm{MQ})($ bacterial \\
inoculums); The toxin breaking points $(\mathrm{MBCs} 50 \mathrm{mg} / \mathrm{mL})$ against Bacillus cereus \\
bacteria after $24 \mathrm{~h}$ incubation.
\end{tabular}

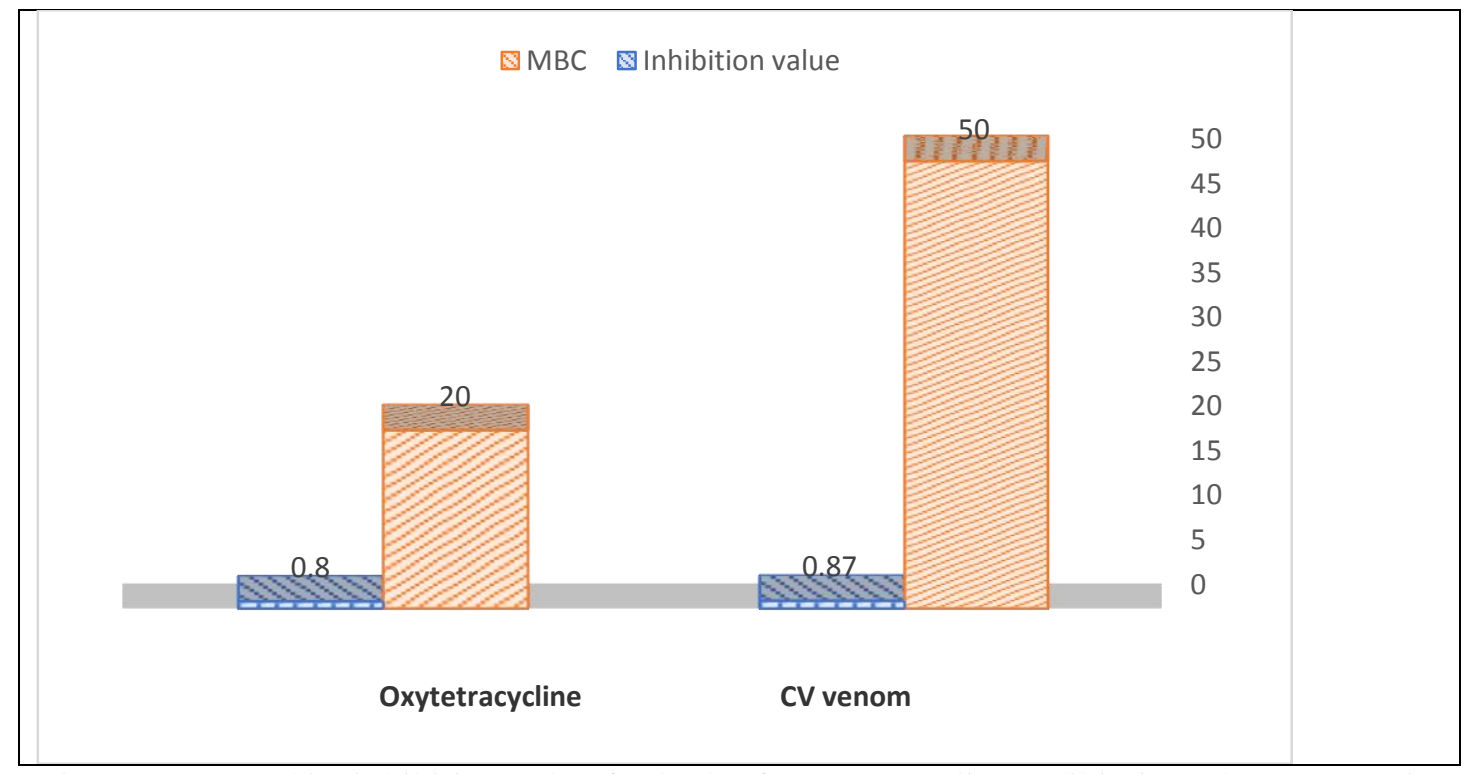

Fig. 8: MBC and its inhibition value for both of oxytetracycline antibiotic and $C v$ venom in the case of Bacillus cereus 


\section{Experiment III: Electron microscope examination}

A) Model of gram-negative bacteria: Pseudomonas aeruginosa

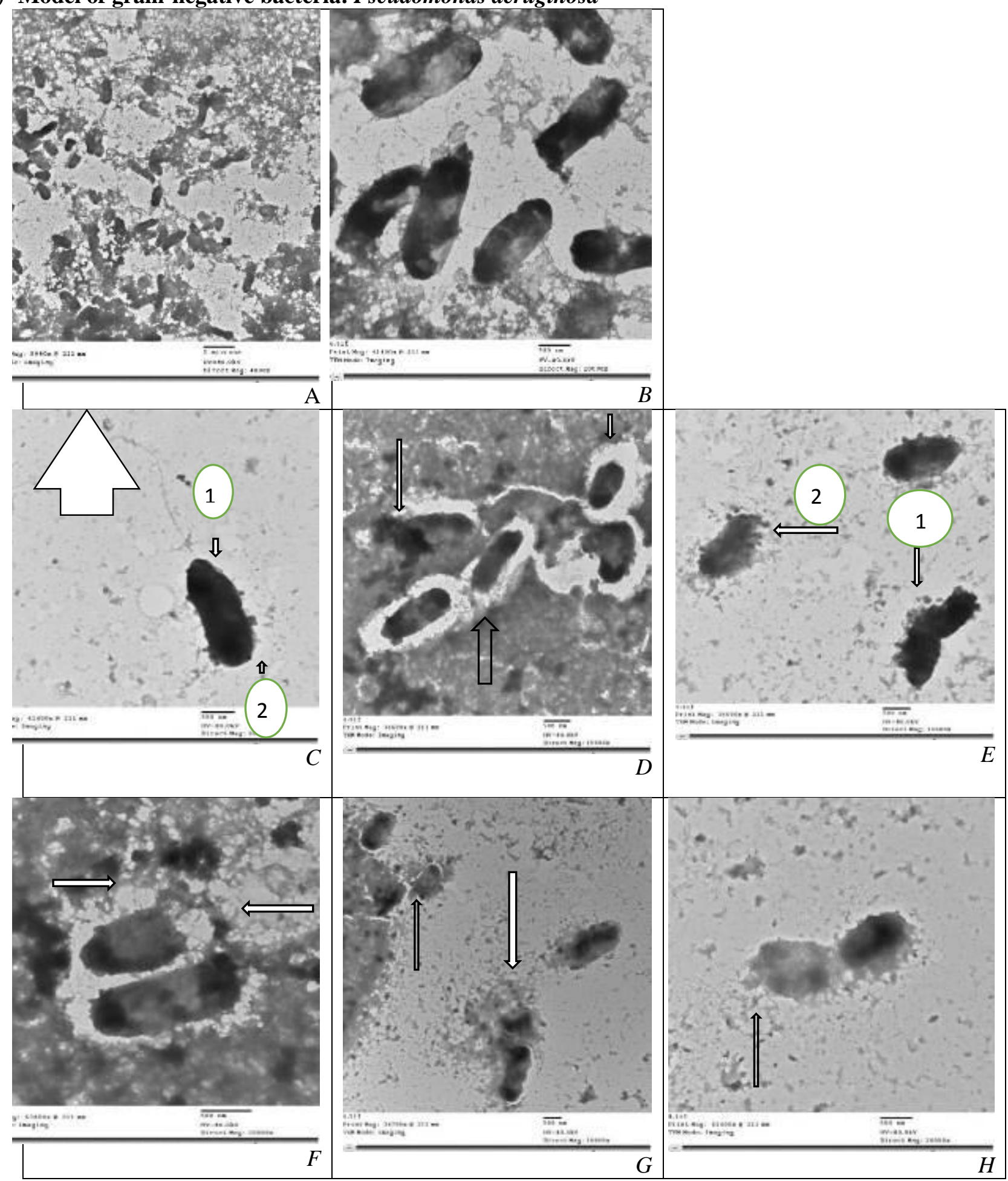

Fig. 9: TEM of untreated (control) and treated $P$. aeruginosa with C. vipera venom

The untreated (control) cells of $P$. aeruginosa appeared bacilli and without visible abnormalities. The formation of a septum was also observed, which indicated that active proliferation was occurring. The cells were separated from each other and displayed a smooth and intact surface with undamaged cell walls (Figure 9A, 9B). After incubation with the MIC of the C. vipera venom for $48 \mathrm{~h}$, the bacteria appeared elongated (fig. 9C1, 9E1). In addition, the cells appeared aggregated compared with the control, some of these melted (fig. 9D). The treated bacterial cells revealed variation in the cell wall thickness and alteration of the shape, which appeared elongated and malformed compared with the control (fig. 9D). Additionally, large spherical non- membrane-enclosed bodies with a similar electron density to that of the septal murein layer were observed in it (Fig. 9F, 9G). There were lysed cells with severely damaged and depleted cell content and with a lamellar form of the cytoplasm were also notice (fig. 9H). 
B) Model of gram-positive bacteria: Bacillus cereus

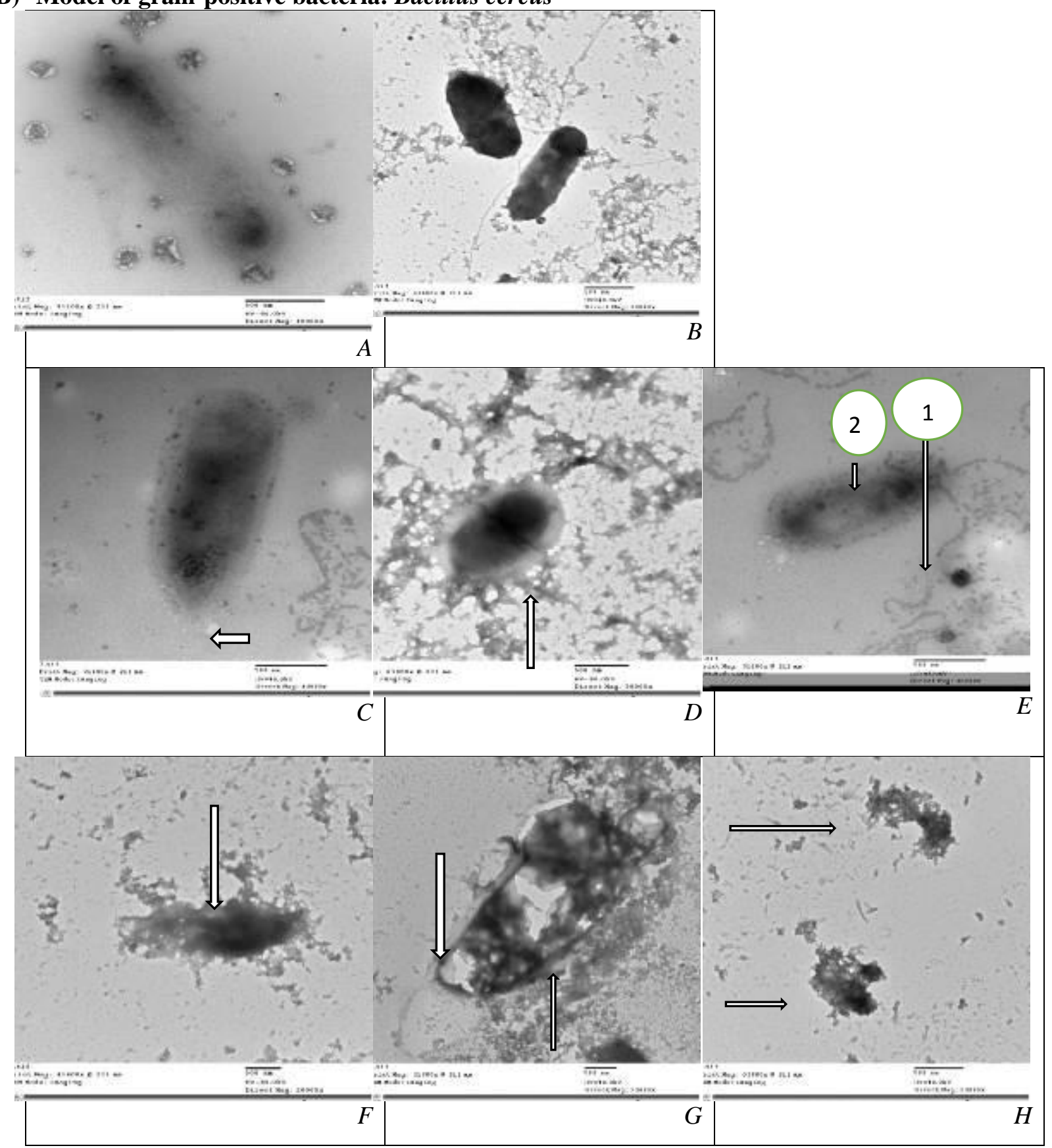

Fig. 10: TEM of untreated (control) and treated B. cereus with C. vipera venom

The untreated (control) cells of B. cereus appeared bacilli and without visible abnormalities. The formation of a septum was also observed, which indicated that active proliferation was occurring. The cells were separated from each other and displayed a smooth and intact surface with undamaged cell walls (Figure 10A, 10B). After incubation with the MIC of the C. vipera venom for $48 \mathrm{~h}$, the bacteria appeared elongated (fig. 10C). In addition, the treated bacterial cells revealed variation in the cell wall thickness and it became more transparent compared with the control (fig 10C, 10E2). Additionally, large spherical non- membrane-enclosed bodies with a similar electron density to that of the septal murein layer were observed in it (Fig. 10E1). The periplasmic space appeared separated, suggesting detachment of the cell wall from the plasma membrane (fig. 10D), and some had holes in their cell wall (Fig. $10 \mathrm{G}$ ). The components of the bacterial cell envelope were deformed and scattered from their original form (Fig. 10E1, 10H). At certain locations of the cells, mostly the septal and polar regions, a draining out of the intracellular contents due to rupture of the cell envelope was noted. Null cells were found (Fig. $10 \mathrm{H}$ ) and many cells without membranes (Fig. $10 \mathrm{~F}$ ). 


\section{DISCUSSIONS}

Antibiotic-resistant bacteria strains are of the top leading causes of death worldwide ${ }^{(4)}$. According to the WHO, they are one of the ten leading causes of death worldwide (13-14). Moreover, antimicrobial resistance is considered to be one of the greatest threats to human health globally ${ }^{(15)}$. In this context, the discovery of new antimicrobial agents is crucial, and the search for new compounds has led to the exploration of various natural sources, such as plant extracts ${ }^{(16-18)}$, bee venom ${ }^{(19)}$, spider venom ${ }^{(20)}$ or snake venom (21). Several studies proved the antibacterial effect of snake venoms ${ }^{(22)}$.

In the present study, first, the identification of Cerastes vipera crude venom evaluated assessment of total protein, Biochemical characterization by SDS page electrophoresis and the assessment of half lethal dose (LD50). The value of total protein of Cerastes vipera venom was equal $1.047 \pm 0.1 \mathrm{mg} / \mathrm{ml}$. This result is in agreement with Abd El - Aal et al. ${ }^{(23)}$ who reported that the Total protein of Cerastes vipera venom is $0.927 \mathrm{mg} / \mathrm{ml}$. In order to make a Comparison between the total protein of Cerastes vipera venom and some other species of Viperidae family, it was mentioned that $1 \mathrm{mg}$ of lyophilized venom of Macrovipera mauritanica contains $1.0 \mathrm{mg}$ of proteins and about $0.987 \mathrm{mg}$ of proteins for Cerastes cerastes venom ${ }^{(24)}$.

Examination of $\mathrm{CV}$ venom using SDS-PAGE electrophoresis revealed that there are four clearbands of protein nearly at $25,35,48,63 \mathrm{Kds}$ and another

.band between 25 , and $35 \mathrm{Kds}$ Our result nearly agrees with that of Labib et al. ${ }^{(25)}$ who observed that there are six major bands. The assessment of LD50 of the Cerastes vipera crude venom was recorded 18.3 $\mu \mathrm{g} / 20$ mouse $(0.915 \mathrm{mg} / \mathrm{kg}$ body weight). This result agrees with that obtained by Mohamed et al. ${ }^{(26)}$ and Hassan et al. ${ }^{(27)}$ who reported that the $C$. vipera venom is lethal in animals (rabbits LD50 $4 \mathrm{mg} / \mathrm{kg}$; mice LD50 $1 \mathrm{mg} / \mathrm{kg}$; rats LD5 $1.3 \mathrm{mg} / \mathrm{kg}$, and doesn't match with that of Abdel-Aty et al. ${ }^{(28)}$ who reported that the LD50 of $C v$ crude venom was recorded at 10 $\mu \mathrm{g} / 21 \mathrm{~g}$ mouse.

Second, the antibacterial activity of Cerastes vipera crude venom against the selective bacterial strains was evaluated by disc diffusion technique, the venom had weak effect against Gram-positive bacteria Bacillus cereus (with inhibition zone $8 \pm 0.2 \mathrm{~mm}$ ) in compared with standard antibiotics Ampicillin $(20 \pm 0.12 \mathrm{~mm})$, Erythromycin $\quad(32 \pm 0.09 \mathrm{~mm}), \quad$ Ciprofloxacin $(40 \pm 0.11 \mathrm{~mm})$ and Amikacin $(28 \pm 0.09 \mathrm{~mm})$ that were highly effective antibacterial. Also, the venom showed acceptable effectiveness against Gram-negative bacteria Pseudomonas aeruginosa (with inhibition zone $12 \pm 0.1 \mathrm{~mm}$ ) in compared with the same standard antibiotics, as this type of bacteria was resistant to Ampicillin and Erythromycin (both with no inhibition zone). Also, Pseudomonas aeruginosa classified as a member of ESKAPE group that reference to their ability to escape the effects of commonly used antibiotics through evolutionarily developed mechanisms ${ }^{(29)}$.

The result was nearly agreed with Salama $\boldsymbol{e t}$ al. ${ }^{(30)}$ who reported that L-amino acid oxidase isolated from Cerastes vipera snake venom displayed bactericidal effect and showed inhibition zone $15 \pm 0.2 \mathrm{~mm}$ against pseudomonas aeruginosa and showed low inhibition zone $8 \pm 0.2 \mathrm{~mm}$ against Bacillus cereus. In contrast, Shebl et al. ${ }^{(31)}$ reported that the venom of both Cerastes cerastes and Vipera lebetina showed no inhibition zone against pseudomonas aeruginosa, this difference due to the variation in Viperidae family species. On the other hand, antibacterial effect was evaluated by assessment the minimum inhibitory concentration (MIC) and minimum bactericidal concentration (MBC).

The result showed The MIC in the case of Bacillus cereus was $25 \mathrm{mg} / \mathrm{ml}$ and $\mathrm{MBC}$ was $50 \mathrm{mg} / \mathrm{ml}$, whereas the MIC in the case of Pseudomonas aeruginosa was $12.5 \mathrm{mg} / \mathrm{ml}$ and $\mathrm{MBC}$ was $25 \mathrm{mg} / \mathrm{ml}$. Our results showed very high level of both MIC and MBC in compared with those of Walaa H. Salama et al. ${ }^{(30)}$ who reported that the minimum inhibitory concentrations (MIC) of the Cerastes vipera L-amino acid oxidase enzyme against the gram-positive strain S. aureus was found to be $20 \mu \mathrm{g} / \mathrm{ml}$, while MIC values of this enzyme against $P$. aeruginosa was found to be $40 \mu \mathrm{g} / \mathrm{ml}$, with consideration that L-amino acid oxidase represent $9 \%$ of cerastes vipera venom, according to Amine Bazaa et al. ${ }^{(32)}$ this difference due to difference between crud venom and effective pure fraction.

Third, the electron microscopic examination for the untreated (control) cells of both P. aeruginosa and B. cereus appeared bacilli and without visible abnormalities. The surface of the bacterial cells appeared smooth with undamaged cell walls. These results were similar to that of Ramar Perumal Samy $\boldsymbol{e t}$ al. ${ }^{(33)}$ who noticed that the untreated bacteria appeared with smooth membrane structure when examined by electron microscope, and agree with Zhang et al. ${ }^{(34)}$ who concluded that the surface of bacteria was smooth with a distinct boundary between the cells. When tested $P$. aeruginosa treated by the $C v$ venom and examined by TEM, it appeared in multiple shapes such as variation in the cell wall thickness, aggregated, melted, elongated, malformed, lysed cells with severely damaged and depleted cell content.

On the other hand, Bacillus cereus treated by the venom also appeared more Transparent, some became polar, the periplasmic space appeared separated (suggesting detachment of the cell wall from the plasma membrane), large spherical non- membraneenclosed bodies appeared, holes in the cell wall, 
draining out of the intracellular contents and null cells were found. These results were similar to that of Samy et al. (33) who reported that bacteria appeared to be losing cell contents and losing of the membrane structure. Also, our results match with Zhang et al. ${ }^{(34)}$ who illustrated that the membrane of bacteria treated with antibacterial protein was largely damaged, resulting in the release of the cell content upon cell wall disruption, with noticeable gaps between the cell membrane and the cytoplasm. Luyang et al. ${ }^{(35)}$, also showed that some venom peptide derivatives had make structural changes and cracks in the cell walls and membranes of the bacteria, causing a release of cell content upon cell wall disruption.

\section{CONCLUSION}

It could be concluded that Cerastes vipera venom is a potentially weak bactericidal, but can inhibit antibiotic-resistant bacteria as Pseudomonas aeruginosa.

\section{REFERENCES}

1. Kasturiratne A, Wickremasinghe AR, de Silva $\mathbf{N}$ et al. (2008): The global burden of snakebite: a literature analysis and modelling based on regional estimates of envenoming and deaths. PLoS Med., 5(11): 218-23.

2. Abu Kashawa SMA, Papenfuss TJ, Alkhedir IS (2018): Geographic Distribution: Cerastes vipera (Sahara Sand Viper). Herpetological Review, 49 (1): 75.

3. O'NEIL J (2014): Antimicrobial Resistance: Tackling a crisis for the health and wealth of nations, Review on Antimicrobial Resistance. https://amr-review.org/

4. Al-Asmari AK, Abbas manthiri R, Nasr eddien $M$ et al. (2015): Assessment of the Antimicrobial Activity of Few Saudi Arabian Snake Venoms. The Open Microbiology Journal, 9: 18-25.

5. Hanane-Fadila ZM, Fatima LD (2014): Purification, characterization and antibacterial activity of L-amino acid oxidase from Cerastes cerastes. J Biochem Mol Toxic., 28:347-354.

6. Samy RP, Pachiappan A, Gopalakrishnakone P et al. (2006): In vitro antibacterial activity of natural toxins and animal venoms tested against Burkholderia pseudomallei. (BMC) Biomedical current Infection Disease, 6(100): 1-16.

7. Lowry OH, Rosebrough NJ, Farr AL et al. (1951): Protein measurement with the Folin phenol reagent. J Biol Chem., 193:265-275

8. Laemmli UK (1970): Cleavage of structural proteins during the assembly of the head of bacteriophage T4. Nature, 227(5259):680-685.

9. Reed LJ, Muench H (1938): A simple method of estimating fifty percent end points. The American Journal of Hygiene, 27(3): 493-497.

10. McFarland J (1907): The nephelometer: an instrument for estimating the number of bacteria in suspensions used for calculating the opsonic index and for vaccines. Journal of the American Medical Association, 49(14): 1176-1178.

11. Bauer AW, Kirby WM, Sherris JC et al. (1966): Antibiotic susceptibility testing by a standardized single disk method. American Journal of Clinical Pathology, 45(4):493-496.

12. Andrews JM (2001): Determination of minimum inhibitory concentrations. Journal of Antimicrobial Chemotherapy, 48(1):5-16.

13. Warburg O, Christian W (1942): Isolation and crystallization of enolase. Biochem Z., 310:384-421.

14. Lopez AD, Mathers CD, Ezzati M et al. (2006): Global burden of disease and risk factors. IBRD/The World Bank and Oxford University Press, Washington, DC. https://www.ncbi.nlm.nih.gov/pubmed/21250374

15. Walker B, Barrett S, Polasky S et al. (2009): Environment. Looming global-scale failures and missing institutions. Science, 325:1345-1346.

16. Munteanu F, Gligor R, Cricirc;snic I et al. (2012): Antimicrobial activity of Melampyrum cristatum, Melampyrum bihariense and Melampyrum arvense tinctures. African J Pharm Pharmacol. Academic Journals, 6(40):2808-12.

17. Tănase C, Coşarcă S, Toma $F$ et al. (2018): Antibacterial activities of beech bark (Fagus sylvatica L.) polyphenolic extract. Environ Eng Manag J., 17(4):877-84.

18. Man A, Santacroce L, Jacob $R$ et al. (2019): Antimicrobial Activity of Six Essential Oils Against a Group of Human Pathogens: A Comparative Study. Pathogen, 8(1):15-8.

19. Han SM, Kim JM, Hong IP et al. (2016): Antibacterial activity and antibiotic-enhancing effects of honeybee venom against methicillin-resistant staphylococcus aureus. Molecules, 2016: 21(1):79.

20. Dubovskii P V, Ignatova AA, Volynsky PE et al. (2018): Improving therapeutic potential of antibacterial spider venom peptides: coarse-grain molecular dynamics guided approach. Future Med Chem., 10(19):2309-22.

21. de Oliveira Junior NG, e Silva Cardoso MH, Franco OL (2013): Snake venoms: Attractive antimicrobial proteinaceous compounds for therapeutic purposes. Cell Mol Life Sci., 70(24):4645-58.

22. Samy RP, Stiles BG, Chinnathambi A et al. (2015): Viperatoxin-II: A novel viper venom protein as an effective bactericidal Agent. FEBS Open Bio., 5 (2015): 928-941.

23. Abd El- Aal A, Abd El-Ghffar EA, Soliman MM (2017): Isolation and Characterization of a Myotoxic Fraction from Cerastes Vipera Snake Venom. J Toxins, 4(1): 1-9.

24. Oukkache $\mathrm{N}_{2}$ Lalaoui $M$, Ghalim N (2012): General characterization of venom from the Moroccan snakes Macrovipera mauritanica and Cerastes cerastes. J Venom Anim Toxins Incl Trop Dis., 18(4):411-420.

25. Labib RS, Awad ER, Farag NW (1981): Proteases of Cerastes cerastes (Egyptian sand viper) and Cerastes vipera (Sahara sand viper) snake venoms. Toxicon, 19: 73-83.

26. Mohamed AH, Saleh AM, Ahmed S et al. (1977): Effects of Cerastes vipera snake venom on blood and bone marrow cells. Toxicon, 15: 35-40.

27. Hassan F, El-Hawary MFS, El-Gahasawy A et al. (1980): Biochemical properties of Egyptian Cerasres venoms in relation to geographic distribution. $\mathrm{Z}$. Ernährungswissenschaft, 19: 259-265 
28. Abdel-Aty AM, Salama WA, Ali AA et al. (2019): A hemorrhagic metalloprotease of Egyptian Cerastes vipera venom: Biochemical and immunological properties. International Journal of Biological Macromolecules, 130: 695-704.

29. Pendleton JN, Gorman SP, Gilmore BF (2013): Clinical relevance of the ESKAPE pathogens. Expert Review of Anti-infective Therapy, 11 (3): 297-308.

30. Salama WH, Ibrahim NM, El Hakim AE et al. (2018): L-Amino acid oxidase from Cerastes vipera snake venom: Isolation, characterization and biological effects on bacteria and tumor cell lines. Toxicon, 150: 270-279

31. Shebl RI, Mohamed AF, Ali AE et al. (2012). Antimicrobial Profile of Selected Snake Venoms and Their Associated Enzymatic Activities. British Microbiology Research Journal, 2(4): 251-263
32. Bazaa A, Marrakchi N, El Ayeb M et al. (2005): Snake venomics: Comparative analysis of the venom proteomes of the Tunisian snakes Cerastes cerastes, Cerastes vipera and Macrovipera lebetina. Proteomics, 5: 4223-4235

33. Samy RP, Stiles BG, Chinnathambi A et al. (2015). Viperatoxin-II: A novel viper venom protein as an effective bactericidal agent. FEBS Open Bio., 5: 928941.

34. Zhang Z, Wang J, Zhang B et al. (2013). Activity of antibacterial protein from maggots against Staphylococcus aureus in vitro and in vivo. International Journal of Molecular Medicine, 31: 1159-1165.

35. Luyang C, Chao D, Zhongjie $L$ et al. (2012): Antibacterial Activity and Mechanism of a Scorpion Venom Peptide Derivative In Vitro and In Vivo. PLoS ONE, 7(7): e40135. 